\title{
MENYAMAKAN POLA PIKIR ORANGTUA, GURU, DAN SISWA : SEBUAH USAHA MEMPERKENALKAN GAWAI SECARA BIJAK
}

\author{
SYNCHRONIZING TEACHERS, PARENTS, AND CHILDREN'S \\ MINDSET : AN ATTEMPT TO INTRODUCE THE WISE USE OF GADGET
}

\author{
Nine Febrie Novitasari \\ Universitas Abdurachman Saleh Situbondo \\ Email: ninefebrie@gmail.com
}

\begin{abstract}
Abstrak: Penggunaan teknologi oleh anak bukanlah hal yang baru. Saat ini, hampir semua anak memiliki gawai sendiri seperti telepon pintar, tablet, atau laptop. Sayangnya, penggunaan gawai oleh anak seringkali tanpa melalui pengawasan yang cukup dari orangtua di rumah. Beberapa orangtua memberikan gawai kepada anak mereka dan memberikan akses untuk menggunakannya tanpa adanya kontrol terhadap apa saja yang dilakukan anak dengan gawai mereka. Sebagai pengganti orangtua di sekolah, guru juga memiliki peranan yang penting dalam membantu pengawasan penggunaan gadget oleh anak. Namun sayangnya, beberapa guru masih tidak sadar bahwa peranan mereka cukup signifikan dalam menanamkan pemahaman ini pada anak. Hal ini dibuktikan dengan masih banyaknya bentuk penyalahgunaan gawai oleh anak saat di sekolah. Padahal, jika digunakan secara tepat, gawai memiliki manfaat yang sangat banyak dalam mendukung proses belajar anak di sekolah. Terkait dengan hal ini, kami mencoba memberikan sosialisasi pada guru, wali murid, dan siswa di SDN 1 Seletreng tentang pentingnya kerjasama antara orangtua dan guru dalam memperkenalkan gawai secara bijak pada anak. Dengan adanya sosialisasi ini diharapkan anak memiliki pemahaman yang baik sejak dini tentang dampak positif dan dampak negatif dari penggunaan gawai. Tujuan jangka panjang dari kegiatan ini adalah adanya kerjasama yang baik antara orangtua dan sekolah (dalam hal ini guru) untuk bersama-sama mendidik dan menanamkan potensi yang baik bagi anak terutama dalam kaitannya dengan penggunaan gawai dalam mendukung pendidikan dan perkembangana anak baik secara kognitif, afektif, dan psikomotor. Hasil dari kegiatan ini adalah adanya respon positif berupa pemahaman orangtua dan guru tentang penggunaan gawai pada anak, dan adanya usaha-usaha nyata yang dilakukan untuk mengawasi penggunaan gawai oleh anak.
\end{abstract}

Kata Kunci: gawai, sosialisasi, guru, orangtua, siswa

\begin{abstract}
It is no secret that children nowadays are called technology-and-gadget natives. Almost all children have their own devices such as smartphones, tablets, or laptops. Unfortunately, the use of devices by children is often without sufficient supervision from parents at home. Some parents give their children a device and provide access to use it without any control over what the child is doing with their device. As a substitute for parents at school, teachers also have an important role in helping to monitor the use of gadgets by children. However, unfortunately, some teachers are still not aware that their role is quite significant in instilling this understanding in children. This is evidenced by the misuse of suh devices by children while at school. In fact, if used appropriately, the devices have many benefits in supporting the learning process of children. In this regard, we try to provide socialization to teachers, parents, and students at SD Negeri 1 Seletreng about the importance of cooperation between parents and teachers in
\end{abstract}




\section{INTEGRITAS : Jurnal Pengabdian}

Vol 4, No 1, Juli 2020

ISSN $2580-7978$ (cetak) ISSN 2615-0794 (online)

introducing the device wisely to children. With this socialization, children are expected to have a good understanding early on about the positive and negative effects of using a device. The long-term goal of this activity is a good collaboration between parents and school (in this case the teacher) to jointly educate and instill good potential for children especially in relation to the use of devices to support children's education and development both cognitively, affective and psychomotor. The results of this activity are positive responses in the form of parents 'and teachers' understanding of the use of devices in children, and the existence of concrete efforts made to monitor the use of devices by children.

Keywords: gadget, teachers, parents, children, socialisation

\section{PENDAHULUAN}

Penggunaan gawai oleh anak di jaman sekarang bukanlah lagi menjadi hal yang baru. Di era serba teknologi ini, hampir semua anak (bahkan sejak di tingkat sekolah dasar) telah mengenal dan memiliki gawai sendiri seperti telepon pintar, tablet, atau laptop. Kepemilikan dan penggunaan gawai oleh anak tidak hanya terjadi di daerah perkotaan. Di daerah pinggir kota pun, anak-anak telah mengenal dan memiliki gawai sendiri. Walaupun tidak sebanyak di kota, namun jumlah penggunaan gawai oleh anak tingkat sekolah dasar sudah cukup tinggi. Beberapa penelitian telah membuktikan tingginya penggunaan gawai pada anak (Chusna, 2017; Harususilo, 2018; Witrsa dkk, 2018; Chaidirman dkk, 2019). Hal ini tentu saja berpengaruh terhadap perkembangan anak, baik secara fisik maupun mental. Hal ini didukung oleh pernyataan dari Natalova (2019) yang menjelaskan bahwa intensitas tinggi penggunaan gawai pada anak dapat merusak empat area utama yaitu tidur, berat badan, perkembangan sosial, dan kesehatan mental. Lebih jauh, Natalova juga mengatakan bahwa terdapat efek yang saling berkaitan antara perkembangan fisik dan perkembangan mental anak. Jika (misal) perkembangan fisik anak terganggu, maka akan berakibat perkembangan mentalnya juga terganggu.

Sejatinya perkembangan hidup anak yang mencakup perkembangan fisik dan mental adalah tanggung jawab orangtua. Jailani (2018) menjabarkan bahwa tugas orangtua tidak hanya memenuhi kebutuhan fisik anak, namun juga memberi perhatian, bimbingan, arahan, motivasi, dan pendidikan, serta penanaman nilai. Sejalan dengan Jailani, Anshori (2009) mengatakan bahwa tanggung jawab 


\section{INTEGRITAS : Jurnal Pengabdian}

Vol 4, No 1, Juli 2020

ISSN $2580-7978$ (cetak) ISSN 2615 - 0794 (online)

orangtua tidak hanya mengasuh anak, namun juga mempersiapkan pertumbuhan jiwa, raga, dan sifat anak hingga dewasa agar nantinya mampu menjalankan kehidupan bermasyarakat. Nyata di sini bahwa peran orangtua tidaklah mudah. Keluarga menjadi lingkungan yang vital dalam perkembangan anak. Namun, selain keluarga, sekolah juga menjadi tempat yang memiliki peran penting terhadap perkembangan anak. Guru di sekolah sebagai pengganti orangtua juga memiliki peran yang tidak kalah rumit dari tugas orangtua di rumah. Peran guru di sekolah haruslah mendukung tanggung jawab orangtua di sekolah sehingga dapat saling memberikan kontribusi positif bagi anak. Dengan kata lain, peran guru tidak hanya sebagai pengajar, namun lebih ke menjadi seorang pendidik. Guru harus mampu menjadi orang terdekat anak saat di sekolah sehinggdapat lebih maksimal dalam memberikan pendidikan bagi anak. Oleh karena itu, diperlukan kerjasama antara orangtua dan guru dalam mendidik anak (Jessica, 2018). Pentingnya kerjasama antara orangtua dan guru dalam mendidik anak diutarakan oleh beberapa peneliti terdahulu. Kerjasama yang baik antara orangtua dan guru memiliki banyak manfaat, seperti meningkatkan kecerdasan emosional, hasil belajar, sikap, keterampilan, kreatifitas anak, dan pendidikan agama (Rahman, 2014; Mudhoffar, 2015; Pusitaningtyas, 2017)

Kerjasama yang baik antara orangtua dan guru di sekolah juga mencakup pengawasan terhadap sikap dan kebiasaan anak dalam penggunaan gawai. Jenis gawai yang biasanya diberikan orangtua pada anak adalah telepon pintar. Pada umumnya, alasan orangtua memberikan gawai pada anak adalah sebagai alat hiburan. Rahayu (2015), dalam penelitiannya menemukan bahwa terdapat beberapa motif orangtua memberikan gawai pada anaknya, yaitu untuk menyenangkan anaknya, agar anak tidak ketinggalan jaman, agar anak lebih betah di rumah, sebagai hadiah, dan sebagai alat bermain. Beberapa alasan yang sama juga didapat dari penelitian survei dari Nielsen dalam 2016 Mobile Kids Report (Andi, 2017). Dari hasil survei tersebut ditemukan fakta bahwa dengan memberikan anak gawai, orangtua berpikir akan lebih mudah memantau dan mengontrol anak, memperlancar akses komunikasi dengan anak, mengenalkan 


\section{INTEGRITAS : Jurnal Pengabdian}

Vol 4, No 1, Juli 2020

ISSN $2580-7978$ (cetak) ISSN 2615-0794 (online)

teknologi pada anak sejak dini, memenuhi permintaan anak, dan karena orangtua mampu membelikan gawai untuk anak.

Namun sayangnya masih banyak orangtua dan guru yang kehilangan atau lepas pengawasan terhadap penggunaan gawai seperti telepon pintar oleh anak. Banyak dari ornagtua dan guru yang tidak mengetahui adanya efek negatif penyalahgunaan telepon pintar oleh anak. Mereka biasanya hanya mengetahui bahwa anak menggunakan telepon pintar untuk bermain game atau melakukan chat dengan teman-temannya. Hal ini diperparah jika bahkan orangtua dari si anak malah tidak memiliki telepon pintar sehingga makin minim akses mereka pada perangkat pintar yang dimiliki anak. Permasalahan penyalahgunaan gawai khususnya telepon pintar oleh anak juga ditemukan pada siswa SDN 1 Seletreng. Walaupun tidak semua siswa memiliki telepon pintar, namun mereka yang memiliki telah menunjukkan beberapa penyalahgunaan, seperti penggunaan di saat pelajaran berlangsung dan bermain game yang mengandung unsur kekerasan. Dari wawancara awal, didapatkan informasi bahwa guru di sekolah tersebut tidak begitu menaruh perhatian terhadap isu tersebut. Sekolah juga belum pernah mengadakan koordinasi dengan wali murid untuk membahasa perkembangan emosional siswa. Satu-satunya pertemuan antara guru dan wali murid adalah sata penerimaan hasil belajar siswa (raport). Maka dari inilah, kami berusaha menjembatani dan menawarkan solusi untuk mencegah terjadinya penyalahgunana gawai lebih jauh lagi. Solusi berupa sosialisasi tentang bahaya gawai oleh anak dan bagaimana peran orangtua dan guru untuk meminimalisir hal tersebut. Siswa juga menjadi sasaran dari kegiatan ini karena mereka adalah objek utama dari kegiatan sosialisasi sehingga mereka juga harus dikenalkan pada caracara penggunaan telepon pintar yang bijak di umur mereka.

Beberapa kegiatan pengabdian pada masyarakat dengan tujuan serupa pernah dilakukan sebelumnya, seperti yang telah dilaksanakan oleh Lensoni dkk (2019), Rozas (2019), Roza (2018), dan Wanto dkk (2018). Lensoni dkk mencoba memberikan solusi kepada siswa SMK tentang bahya gawai bila tidak digunakan dengan bijak dan hubungannya dengan perkembangan pemebntukan karakter 


\section{INTEGRITAS : Jurnal Pengabdian}

Vol 4, No 1, Juli 2020

ISSN $2580-7978$ (cetak) ISSN 2615-0794 (online)

mereka melalui pendekatan cean diskusi. Rozas mencoba menawarkan sebuah kebijakan bernama GWS (Gadget Warning System) sebagai upaya pengawasan dan pembataan penggunaan gawai oleh anak dan remaja. Roza memberikan pelatihan bagi orang tua tentang peran penting mereka dalam menjaga anak-anak dari bahaya gawai yang mengintai dengan cara memebrikan pengetahuan bagaimana mengoptimalkan fitur keamanan yang terdapat pada aplikasi dalam gawai. Terakhir, Wanto memebrikan pelatihan dam bimbingan bagi siswa SMK Anak Bangsa dalam menggunakan Internet dengan cara yang bijaksana. Melihat keberhasilan kegiatan-kegiatan tersebut, maka kami melaksanakan kegiatan yang bertujuan memberikan pemahaman bagi orangtua, guru, dan juga siswa sekaligus tentang bahya penggunaan gawai sekaligus cara koordinasi antara orangtua dan guru untuk mencegah penyalahgunaan gawai oleh siswa di SDN 1 Seletreng.

SDN 1 Seletreng beralamat di Jl. PP Sumber Bunga, RT.0/RW.0. Pademin, Seletreng, Kapongan, Situbondo. Sekolah ini dipimpin oleh $\mathrm{Hj}$. Hasanah, M.Pd. selaku kepala sekolah. Sekolah ini terakreditasi B, memiliki total sembilan guru dan delapan puluh dua siswa (Data Pokok Pendidikan Dasar dan Menegah, 2020).

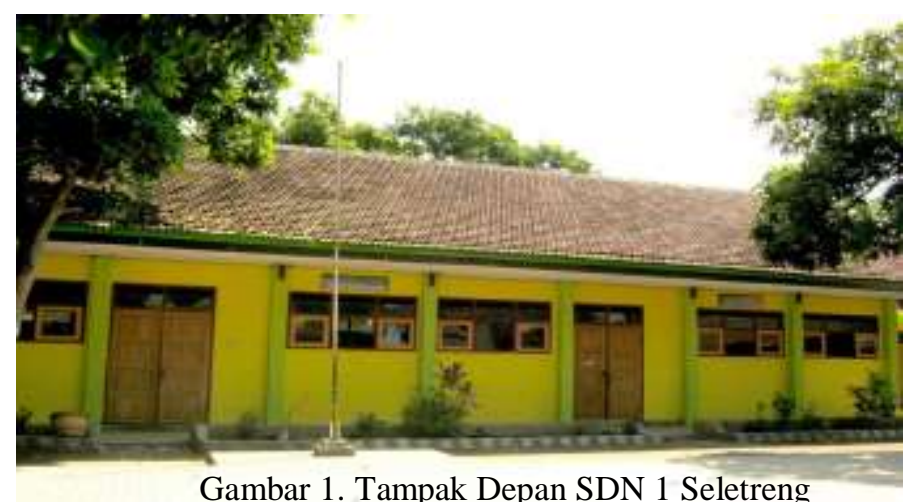

\section{METODE PELAKSANAAN}

Permasalahan yang menjadi fokus bahasan pelaksanaan kegiatan ini bila dijabarkan yaitu kurangnya pengawasan orang tua dan guru terhadap anak dalam hal penggunaan telepon pintar oleh anak, tidak adanya koordinasi yang baik 


\section{INTEGRITAS : Jurnal Pengabdian}

Vol 4, No 1, Juli 2020

ISSN $2580-7978$ (cetak) ISSN 2615-0794 (online)

antara guru dan orang tua siswa dalam mendidik anak, kurangnya pemahaman orang tua, guru, dan anak tentang penggunaan telepon pintar secara bijak, dan adanya penyalahgunaan telepon pintar oleh anak. Bila dirangkum, permasalahan dan solusi yang kami berikan dapat dilihat pada Tabel 1 .

Tabel 1. Permasalahan dan Solusi yang Ditawarkan.

\begin{tabular}{|c|c|c|}
\hline No & Permasalahan & Solusi \\
\hline 1 & $\begin{array}{l}\text { Kurangnya pengawasan } \\
\text { orangtua dan guru terhadap anak } \\
\text { dalam menggunakan telepon } \\
\text { pintar. }\end{array}$ & $\begin{array}{l}\text { Memberikan pemahaman kepada orangtua dan } \\
\text { guru tentang pentingnya peran mereka dalam } \\
\text { pengawasan terhadap penggunaan telepon } \\
\text { pintar oleh anak. }\end{array}$ \\
\hline 2 & $\begin{array}{l}\text { Tidak adanya koordinasi yang } \\
\text { baik antara orangtua dan guru } \\
\text { dalam mendidik anak. }\end{array}$ & $\begin{array}{l}\text { Memberikan pemahaman terhadap orangtua } \\
\text { dan guru tentang manfaat koordinasi yang baik } \\
\text { antara orangtua dan guru dalam mendidik } \\
\text { anak. }\end{array}$ \\
\hline 3 & $\begin{array}{l}\text { Kurangnya pemahaman } \\
\text { orangtua, guru, dan anak tentang } \\
\text { penggunaan telepon pintar } \\
\text { secara bijak. }\end{array}$ & $\begin{array}{l}\text { - Memberikan pemahaman terhadap orangtua, } \\
\text { guru, dan anak tentang penggunaan telepon } \\
\text { pintar secara bijak. } \\
\text { - Memberikan pelatihan cara pemanfaatn } \\
\text { telepon pintar dengan bijak. }\end{array}$ \\
\hline 4 & $\begin{array}{l}\text { Penyalahgunaan telepon pintar } \\
\text { oleh anak. }\end{array}$ & $\begin{array}{l}\text { Memberikan pemahaman bagi orangtua, guru, } \\
\text { dan anak tentang dampak negatif penyalah } \\
\text { gunaan telepon pintar. }\end{array}$ \\
\hline
\end{tabular}

Metode yang kami tawarkan untuk menyelesaikan masalah-masalah tersebut diwujudkan dalam bentuk metode sosialisasi yang dibagi menjadi tiga sesi yaitu ceramah, diskusi, dan praktik. Kegiatan ini dilaksanakan pada hari Sabtu, 11 Januari 2020 di SDN 1 Seletreng dari pukul 08:00 hingga pukul 14:00 WIB. Target dari kegiatan ini adalah adanya pemahaman yang baik dari orangtua, guru, dan anak tentang penggunaan telepon pintar secara bijak sehingga tidak lagi muncul penyalahgunaan telepon pintar oleh anak.

Secara spesifik, berikut penjabaran dari ketiga sesi kegiatan.

1. Ceramah

Pada sesi ini, materi yang diberikan ada beberapa yaitu:

a. Sejarah perkembangan gawai

b. Bentuk-bentuk penyalahgunaan gawai

c. Efek negatif penyalahgunaan gawai 

d. Cara menyiasati penyalahgunaan gawai
e. Peranan orangtua
f. Contoh penggunaan gawai yang bermanfaat

2. Diskusi

Sesi diskusi memberi kesempatan peserta kegiatan (orangtua, guru, dan siswa) untuk menanyakan beberapa hal yang dirasa tidak jelas dan belum dipahami. Pada sesi ini juga diadakan sesi tanya jawab dari pelaksana kegiatan kepada peserta kegiatan untuk mengukur tingkat pemahaman mereka terhadap materi yangs udah diberikan.

Gambaran IPTEK metode pelaksanaan kegiatan ini dapat dilihat pada Gambar 1.

\section{PKM USAHA MEMPERKENALKAN PENGGUNAAN GAWAI DENGAN BIJAK}

\section{Permasalahan:}

1. Kurangnya pengawasan orangtua dan guru terhadap anak dalam menggunakan telepon pintar.

2. Tidak adanya koordinasi yang baik antara orangtua dan guru dalam mendidik anak.

3. Kurangnya pemahaman orangtua, guru, dan anak tentang penggunaan telepon pintar secara bijak.

4. Penyalahgunaan telepon pintar oleh anak.

\section{Solusi:}

Sosialisasi dengan pendekatan:

1. Ceramah

2. Diskusi

Luaran

1. Peningkatan kualitas orang tua dan guru dalam mendidik anak.

2. Peningkatan pemahaman orangtua, guru, dan anak tentang penggunaan telepon pintar secara bijak.

Gambar 2. Gambaran IPTEK Pelaksanaan Kegiatan 


\section{INTEGRITAS : Jurnal Pengabdian}

Vol 4, No 1, Juli 2020

ISSN $2580-7978$ (cetak) ISSN 2615-0794 (online)

\section{HASIL DAN PEMBAHASAN}

Tujuan utama dari dilaksanakannya kegiatan ini adalah untuk meningkatkan kualitas orangtua dan guru dalam mendidik anak, utamanya dalam hal penggunaan telepon pintar dan meminimalisir terjadinya penyalahgunaan telepon pintar oleh anak. Seperti yang telah dijelaskan sebelumnya, untuk mencapai tujuan tersebut, solusi yang diberikan adalah dalam bentuk sosialisasi dengan pendekatan ceramah, diskusi, dan praktek. Berikut deskripsi hasil kegiatan secara rinci.

Kegiatan sosialisasi ini berlangsung selama satu hari, yaitu pada hari Sabtu, 11 Januari 2020 bertempat di SDN 1 Seletreng. Kegiatan berlangsung selama kurang lebih enam jam, yaitu dari pukul 08:00 sampai dengan pukul 13:00 WIB. Jumlah peserta yang hadir adalah lima orang guru, tujuh orang wali murid, dan tiga belas siswa. Sosialisasi ini dibagi menjadi dua sesi yaitu sesi ceramah dan sesi diskusi.

\section{Ceramah}

Sesi ini berlangsung dari pukul 08:00 - 11:00. Sesi ceramah dibagi menjadi dua bagian. Bagian pertama diberikan oleh Pelaksana 1 (Nine Febrie Novitasari, S.Pd., M.Pd.) dan bagian kedua diberikan oleh Pelaksana 2 (Ahmad Yusuf Firdaus, S.S., M.Hum). materi yang diberikan mencakup:

a. Sejarah perkembangan gawai

Peserta diperkenalkan dengan awal munculnya gawai, jenis-jenis gawai, dan perubahan bentuk gawai dari awal hingga sekarang.

b. Bentuk-bentuk penyalahgunaan gawai

Peserta diberi contoh bentuk-bentuk penyalahgunaan gawai yang dilakukan oleh baik orang dewasa maupun anak-anak, seperti:

- Penggunaan gawai secara berlebihan

- Meniru hal negatif dari Internet

- Bermain game yang mengandung unsur kekerasan,

- Mengakses hal-hal yang mengandung unsur SARA 


\section{INTEGRITAS : Jurnal Pengabdian}

- Menyebarkan kabar yang tidak dapat dipertanggung jawabkan kebenarannya (hoax)

- Menggunakan gawai tidak sesuai waktu dan tempat

c. Efek negatif penyalahgunaan gawai

- Cahaya biru telepon pintar yang berbahaya bagi mata

- Radiasi telepon pintar yang berbahaya bagi otak

- Peserta diberi contoh efek negatif dari penyalahgunaan gawai seperti:

- Kecanduan

- Imitasi hal negatif dari Internet

- Rasa malas untuk belajar

- Anti sosial

- Boros pulsa data

- Pencurian

- Bullying (perundungan)

- Judi online

- Ancaman keselamatan

d. Cara menyiasati penyalahgunaan gawai

- Tahu kapan harus menggunakan gawai

- Mengurangi penggunaan gawai

- Menyibukkan diri dengan aktivitas lain

- Memakai telepon biasa

- Meminta bantuan dan pendampingan orang tua/guru saat memakai gawai

e. Peranan orangtua

- Mendampingi anak saat memakai gawai

- Mengurangi frekuensi penggunaan gawai oleh anak

- Menyibukkan anak dengan aktivitas lain

- Membawa anak untuk bersosialisasi 


\section{INTEGRITAS : Jurnal Pengabdian}

- Tidak memberi gawai sebelum anak berusia 15 tahun

- Mengatur penggunaan aplikasi gawai

- Memberikan hadiah bila anak bisa lepas dari gawai

f. Contoh penggunaan gawai yang bermanfaat

- Sebagai sumber belajar digital

- Media hiburan sambil belajar

- Alat komunikasi dengan keluarga dan guru

g. Cara mengatur aplikasi pada telepon pintar

Pada sesi ini peserta, khususnya wali murid dan guru diberi pemahaman tentang pentingnya pengaturan aplikasi pada telepon pintar yang dipakai anak. Hal ini dapat dilakukan dengan beberapa cara seperti:

- Mengunci aplikasi

- Mengatur pencarian pada Internet

- Mengintall aplikasi khusus anak, misal Youtube Kids

- Memantau game dan aplikasi lain yang digunakan anak

- Mengunci gawai

h. Koordinasi antara orangtua dan guru

Koordinasi antara orangtua dan wali murid sebaiknya dilakukan rutin baik secara formal maupun informal. Selain saat penerimaan raport, sebaiknya orangtua juga rutin berhubungan dan berkoordinasi dengan guru untuk memantau perkembangan anak di sekolah. Jadi misal terjadi sesuatu yang dirasa tidak benar pada anak, orangtua dan guru dapat segera melakukan tindakan preventif. Di sini peserta yaitu wali murid dan guru disarankan untuk memiliki grup WA atau saling menyimpan nomor guru dan orangtua sehingga memudahkan dalam koordinasi.

Dalam sesi ini, materi diberikan dalam bentuk gambar yang ditayangkan pada slide dan gambar cetak. Peserta terlihat antusias menyimak materi yang diberikan, terutama wali murid yang rata-rata tidak 


\section{INTEGRITAS : Jurnal Pengabdian}

Vol 4, No 1, Juli 2020

\section{ISSN $2580-7978$ (cetak) ISSN 2615-0794 (online)}

mengetahui bahwa gawai, khususnya telepon pintar dapat memiliki efek negatif yang dampaknya sangat vital bagi pertumbuhan dan perkembangan anak mereka. Selain itu, banyak dari wali murid yang baru mengetahui bahwa cahaya biru dan radiasi pada telepon pintar dapat membahayakan kesehatan.

Hasil dari sesi ini jika dirangkum adalah sebagai berikut:

a. Orangtua, guru, dan anak belum mengetahui efek dari cahaya biru dan radiasi pada telepon pintar bagi kesehatan.

b. Orangtua, guru, dan anak belum seutuhnya memahami efek negatif dari pemberian telepon pintar pada anak di usia SD.

c. Orangtua dan guru belum pernah melakukan koordinasi dalam memantau perkembangan anak.

d. Orangtua selama ini tidak begitu keras dalam mengawasi penggunana telepon pintar oleh anak.

e. Guru tidak begitu perhatian terhadap siswa yang memiliki telepon pintar, termasuk saat mereka menggunakannya dalam kelas.

f. Anak tidak mengetahui bahwa ada efek negatif dari game yang mereka mainkan.

g. Anak tidak memahami bahwa penggunaan telepon pintar dalam waktu lama adalah salah satu bentuk penyalahgunaan gawai.

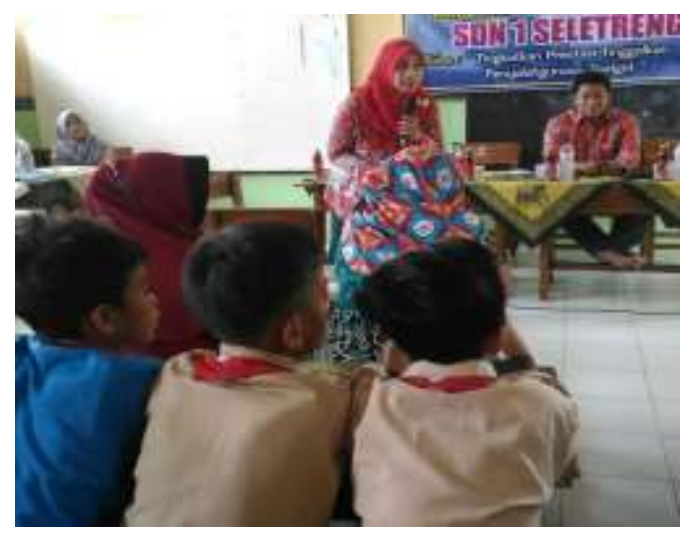

Gambar 3. Pemberian Materi 1 


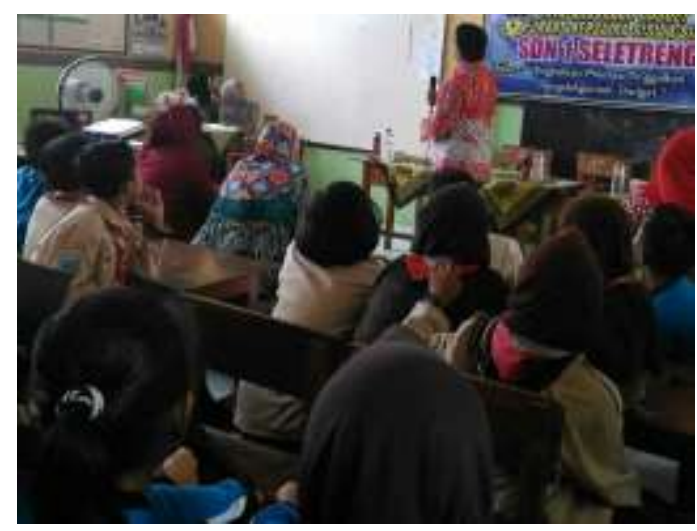

Gambar 4. Pemberian Materi 2

\section{Diskusi}

Terkait dengan permasalahan dan temuan yang didapat dari sesi ceramah, maka sesi diskusi ini diberikan untuk memberi kesempatan orangtua, guru, dan anak untuk menyelesaikan permasalahan yang ada. Sesi ini berlangsung dari pukul 11:00 sampai pukul 13:00. Pada sesi ini, kesempatan bertanya diberikan kepada semua peserta. Dari hasil diskusi, peserta telah memahami bagaimana cara terbaik/paling bijak dalam mengawasi penggunaan telepon pintar oleh anak. Peserta terlihat cukup aktif dalam sesi diskusi yang dibuktikan dengan banyaknya pertanyaan yang diberikan. Berikut beberapa pertanyaan yang diberikan saat sesi diskusi.

a. Orangtua

- Mengapa game yang dimainkan anak juga harus dipantau padahal game membantu anak rileks sepulang dari sekolah?

- Mengapa anak sebaiknya tidak diberikan telepon pintar sebelum berusia lima belas tahun?

- Apakah jika anak diberikan telepon biasa dampaknya akan berbeda dari pemberian telepon pintar?

- Apa yang harus dilakukan orangtua yang buta huruf dalam mengawasi anaknya menggunakan telepon pintar?

- Bagaimana cara menolak anak yang minta dibelikan telepon pintar?

- Bolehkah memberikan telepon pintar pada anak sebagai hadiah bila berprestasi di sekolah? 


\section{INTEGRITAS : Jurnal Pengabdian}

Vol 4, No 1, Juli 2020

ISSN 2580-7978 (cetak) ISSN 2615-0794 (online)

b. Guru

- Seberapa besar peranan guru dibandingkan orangtua dalam mengawasi anak?

- Bolehkah guru menyita telepon pinta siswa bila disalahgunakan saat di sekolah?

- Apakah guru punya hak untuk mengakses isi telepon siswa jika ditengarai ada penyalahgunaan oleh siswa?

- Bagaimana menyikapi guru yang kadang malah bermain telepon pintar saat mengajar?

c. Siswa

- Game apa yang cocok dimainkan oleh anak-anak?

- Apakah anak boleh memiliki akun Facebook?

- Kapan anak-anak boleh bermain telepon pintar saat di rumah?

- Bolehkah anak-anak membawa telepon pintar ke sekolah?

Pada sesi ini, peserta diberikan kuis berupa beberapa pertanyaan dan diminta memberikan jawabannya. Terdapat enam pertanyaan yang mencakup peranan orangtua dan guru, penggunaan gawai, dan upaya pencegahan pemakaian gawai oleh anak.

Dari sesi diskusi ini, didapatkan hasil sebagai berikut. Mayoritas orangtua lebih fokus pada tujuan membuat anak bahagia dengan memberikan mereka telepon genggam dan mengesampingkan efek dari penggunaan telepon genggam oleh anak. Anak-anak juga lebih suka menggunakan telepon pintar mereka untuk hal-hal yang bersifat hiburan seperti bermain game dan bercakap-cakap dengan temannya melalui aplikasi chatting. Sedangkan guru lebih khawatir pada kegiatan akdemik di kelas daripada menaruh perhatian lebih pada individual di kelas. Dari sini bisa kita lihat bahwa setelah diberi penjelasan dan jawaban untuk semua pertanyaan yang diajukan, orangtua, guru, dan anak telah memiliki pemahaman yang baik tentang penggunana telepon pintar oleh anak. 


\section{INTEGRITAS : Jurnal Pengabdian}

Vol 4, No 1, Juli 2020

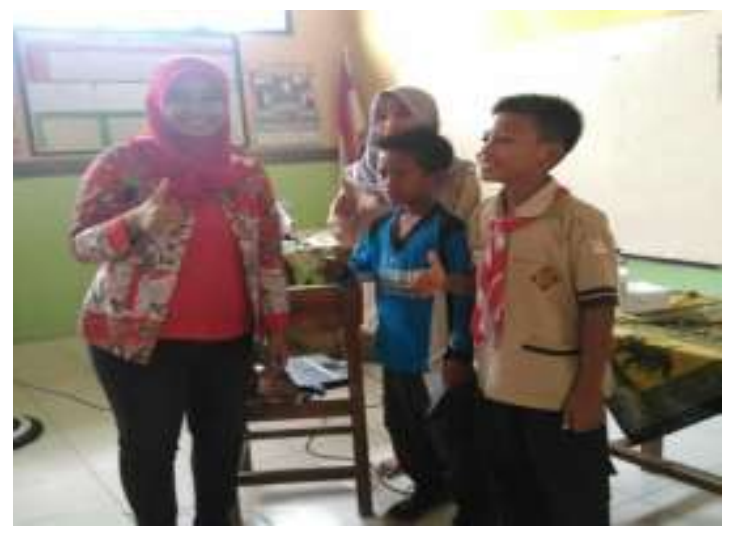

Gambar 5. Diskusi 1

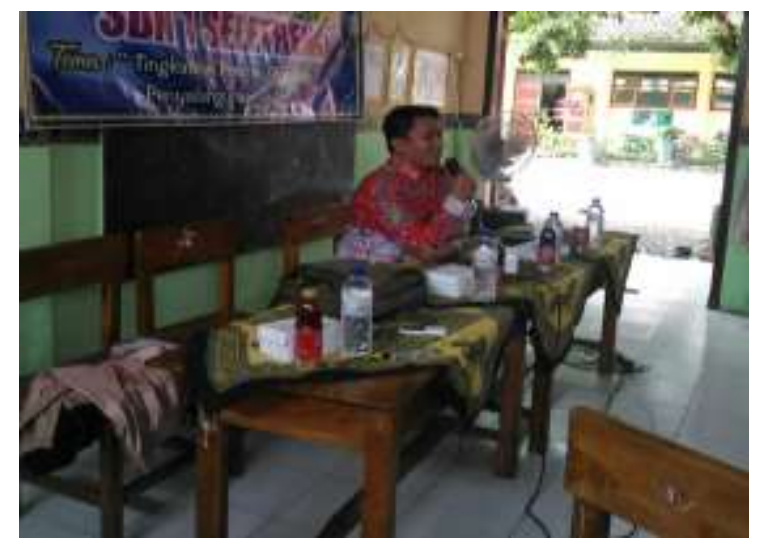

Gambar 6. Diskusi 2

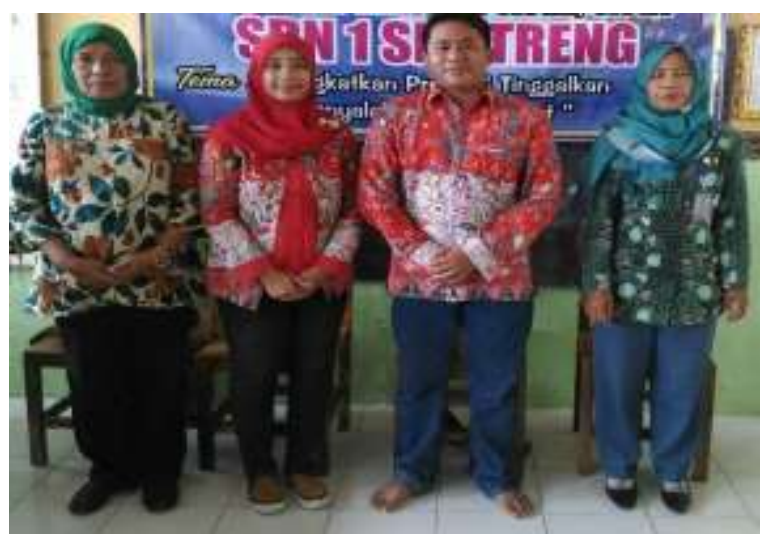

Gambar 7. Foto bersama Guru SD Negeri 1 Seletreng 
INTEGRITAS : Jurnal Pengabdian

Vol 4, No 1, Juli 2020

ISSN $2580-7978$ (cetak) ISSN 2615-0794 (online)

\section{Tahap Tindak Lanjut}

Tahapan tindak lanjut adalah tahapan pascaosialisasi. Tujuan dari kegiatan tindak lanjut ini adalah memastikan bahwa apa yang telah didapatkan dari kegiatan sosialisasi segera dapat diaplikasikan dalam kehidupan peserta kegiatan. Tahap tindak lanjut dilaksanakan satu minggu setelah kegiatan sosialisasi. Pada saat sosialisasi, sebelum pulang, peserta diberi form kuesioner untuk memantau kegiatan mereka terkait penggunaan telepon pintar oleh anak. Kuesioner ini dibagi menjadi dua jenis: kuesioner untuk guru dan kuesioner untuk orang tua. Sayangnya tidak semua peserta mengembalikan kuesioner yang dibagikan. Hanya enam kuesioner orangtua dan tiga kuesioner guru yang dikumpulkan. Luaran yang ditargetkan sebagai tujuan utama dari kuesioner ini adalah adanyapeningkatan pengawasan dari orangtua dan guru terhadap anak dalam menggunakan telepon pintar, adanya koordinasi yang baik antara orangtua dan guru dalam mendidik anak, peningkatan pemahaman orangtua, guru, dan anak tentang penggunaan telepon pintar secara bijak, dan berkurangnya penyalahgunaan telepon pintar oleh anak. Dari dua sesi sosialisasi dan tahap tindak lanjut,bila dirangkum, hasil dari kegiatan dapat dilihat pada Tabel 2.

Tabel 2. Luaran Kegiatan

\begin{tabular}{llccl}
\hline No & \multicolumn{1}{c}{ Target Luaran } & Tercapai & $\begin{array}{c}\text { Belum } \\
\text { Tercapai }\end{array}$ & Keterangan \\
\hline $\mathbf{1}$ & $\begin{array}{l}\text { Peningkatan pengawasan orangtua } \\
\text { dan guru terhadap anak dalam } \\
\text { menggunakan telepon pintar. }\end{array}$ & $\sqrt{ }$ & & \\
\hline $\mathbf{2}$ & $\begin{array}{l}\text { Adanya koordinasi yang baik } \\
\text { antara orangtua dan guru dalam } \\
\text { mendidik anak. }\end{array}$ & $\sqrt{ }$ & $\begin{array}{l}\text { Guru masih harus } \\
\text { berkoordinasi } \\
\text { dengan kepala } \\
\text { sekolah }\end{array}$ \\
\hline $\mathbf{3}$ & $\begin{array}{l}\text { Peningkatan pemahaman orangtua, } \\
\text { guru, dan anak tentang penggunaan } \\
\text { telepon pintar secara bijak. }\end{array}$ & $\sqrt{ }$ & \\
\hline $\mathbf{4}$ & $\begin{array}{l}\text { Berkurangnya penyalahgunaan } \\
\text { telepon pintar oleh anak. }\end{array}$ & $\sqrt{ }$ & \\
\hline
\end{tabular}




\section{INTEGRITAS : Jurnal Pengabdian}

Vol 4, No 1, Juli 2020

ISSN $2580-7978$ (cetak) ISSN 2615-0794 (online)

\section{KESIMPULAN}

Dari kegiatan ini, kesimpulan yang dapat diambil adalah sebagai berikut. Sosialisasi tentang penggunaan gawai secara bijak pada orangtua dan guru dapat membantu meningkatkan kualitas mereka sebagai orangtua bagi anak yang memiliki peran mendidik. Selain itu, anak juga dapat memiliki kehidupan sosial yang lebih baik jika dapat menggunakan gawai secara bijak. Koordinasi yang penting antara orangtua dan guru dapat mempererat dan menguatkan hubungan batin antara sekolah dan wali murid dalam mendidik anak dan memudahkan dalam memantau perkembangan emosional siswa. Untuk jangka panjang, sosialisasi yang lebih mendetail dan akses yang lebih luas pada peserta diperlukan untuk hasil yang lebih maksimal.

\section{UCAPAN TERIMA KASIH}

Pelaksana mengucapkan terima kasih kepada semua pihak yang telah terlibat dalam kegiatan ini. Terima kasih kami ucapkan kepada: 1) SD Negeri 1 Seletreng yang telah berperan sebagai mitra, 2) Desa Seletreng yang telah memberi perijinan kegiatan, dan 3) LP3M Universitas Abdurachman Saleh Situbondo yang mendukung kegiatan ini secara administratif.

\section{DAFTAR PUSTAKA}

Andi, G. (2017). Ini Sebenarnya Alasan Mengapa Orang Tua Biarkan Anaknya Main Smartphone. Retrieved June 1, 2020, from https://www.labana.id/view/ini-sebenarnya-alasan-mengapa-orang-tuabiarkan-anaknya-main-smartphone/2017/09/11/?fullview

Anshori, H. (2009). Konsep Kewajiban Orang Tua Terhadap Anak pada Masa Neonatal Menurut Ibnu Qayyim Al-Jauziyah. Universitas Muhammadiyah Surakarta.

Chaidirman, Indriastuti, D., \& Narmi. (2019). Fenomena Kecanduan Penggunaan Gawai

( Gadget ) pada Kalangan Remaja Suku Bajo. Journal of Holistic Nursing and Health Science, 2(2), 33-41. https://doi.org/https://doi.org/10.14710/hnhs.2.2.2019.33-41 
Chusna, P. A. (2017). Pengaruh Media Gadget Pada Perkembangan Karakter Anak.

Dinamika Penelitian: Media Komunikasi Penelitian Sosial Keagamaan, $17(2), 315-330$

Data Pokok Pendidikan Dasar dan Menengah Direktorat Jenderal Pendidikan Anak Usia Dini, P. D. dan P. M. (2020). SD Negeri 1 Seletreng. Retrieved January 29, 2020, from https://dapo.dikdasmen.kemdikbud.go.id/sekolah/401A4487B616590B2081

Harususilo, Y. E. (2018). Mengkaji Ulang Penggunaan Gawai pada Anak. Retrieved May 31, 2020, from https://edukasi.kompas.com/read/2018/10/17/19294001/mengkaji-ulangpenggunaan-gawai-pada-anak

Jailani, M. S. (2014). Teori Pendidikan Keluarga dan Tanggung Jawab Orang Tua dalam Pendidikan Anak Usia Dini. Nadwa, 8(2), 245. https://doi.org/10.21580/nw.2014.8.2.580

Jessica. (2018). Peran Guru dan Orang tua dalam Pendidikan. Retrieved May 31, 2020, from https://www.educenter.id/peran-guru-dan-orang-tua-dalampendidikan/

Lensoni, L., Lidiawati, M., Arham, N., Savitri, E., \& Rahmawati, C. (2019). PKM Sosialisasi Dampak Gadget, Bahaya Penyalahgunaan Narkoba dan Pergaulan Bebas. Jurnal Abdimas BSI: Jurnal Pengabdian Kepada Masyarakat, 2(2), 227-233. https://doi.org/10.31294/jabdimas.v2i2.5857

Mudhoffar. (2015). Peran Orang Tua dan Keteladanan Guru dalam Pengarahan Pendidikan Islam. Jurnal Pusaka, 10(2), 4-15. Retrieved from https://journal.uny.ac.id/index.php/cp/article/view/7409/pdf

Mulyani, R. S., Urhananik, \& Haerani, N. R. (2018). Pengaruh penggunaan gadget terhadap kemampuan interaksi sosial siswa sekolah dasar. Pedagogik, VI(1), 9-20.

Natalova, T. (2019). Hubungan Gawai dengan Perkembangan Fisik dan Mental Anak. Retrieved May 31, 2020, from https://www.medcom.id/rona/keluarga/wkBDw31N-hubungan-gawaidengan-perkembangan-fisik-dan-mental-anak

Pusitaningtyas, A. (2017). Pengaruh Komunikasi Orang Tua Dan Guru Terhadap Kreativitas Siswa. Proceedings of the ICECRS, 1(1), 935-942. https://doi.org/10.21070/picecrs.v1i1.632 
Rahayu, M. S. (2015). Motif Orang Tua Memberikan gadget pada Anak ( Studi Kasus : Desa Kampung Baru Kecamatan Kayu Aro Barat Kabupaten Kerinci Provinsi Jambi ). Sekolah tinggi Keguruan dan Ilmu Pendidikan (STKIP) PGRI Sumatera Barat, Padang.

Rahman, B. (2014). Kemitraan Orang Tua Dengan Sekolah Dan. Jurnal Pendidikan Progresif, 4(2), 129-138. Retrieved from http://repository.lppm.unila.ac.id/213/1/

Roza, E., Kamayani, M., \& Gunawan, P. (2018). Pelatihan Memantau Penggunaan Gadget pada Anak. Jurnal SOLMA, 7(2), 208. https://doi.org/10.29405/solma.v7i2.1062

Rozas, I. S. (2019). Gadget Warning System Sebagai Upaya Peningkatan Kualitas Gadget Warning System To Improve the Quality of Education for the Nation $\hat{a} €^{\mathrm{TM}} \mathrm{S}$ Children. Pendidikan Dan Kesehatan Gratis Berkualitas, 337-345. Retrieved from https://jakadpublisher.org/wp-content/uploads/2019/02/IndriSudanawati-Rozas.pdf

Wanto, A., Suhendro, D., \& Windarto, A. P. (2018). Pelatihan dan bimbingan dalam pemanfaatan internet yang baik dan aman bagi pelajar SMK Anak Bangsa Desa Bandar Siantar Kabupaten Simalungun. E-DIMAS: Jurnal Pengabdian Kepada Masyarakat, 9(2), 149-157. 